inOedia $\quad \begin{aligned} & \text { InMedia } \\ & \text { The French Journal of Media Studies }\end{aligned}$

$1 \mid 2012$

Global Film and Television Industries Today

\title{
Global and Local Hollywood
}

Ben Goldsmith, Susan Ward and Tom O'Regan

\section{(2) OpenEdition}

\section{Journals}

Electronic version

URL: http://journals.openedition.org/inmedia/114

DOI: 10.4000/inmedia. 114

ISSN: 2259-4728

\section{Publisher}

Center for Research on the English-Speaking World (CREW)

Electronic reference

Ben Goldsmith, Susan Ward and Tom O'Regan, « Global and Local Hollywood », InMedia [Online], 1 । 2012, Online since 23 March 2012, connection on 07 September 2020. URL : http:// journals.openedition.org/inmedia/114 ; DOI : https://doi.org/10.4000/inmedia. 114

This text was automatically generated on 7 September 2020

(c) InMedia 


\title{
Global and Local Hollywood
}

\author{
Ben Goldsmith, Susan Ward and Tom O'Regan
}

1 The concept of 'Global Hollywood' is extremely useful. ${ }^{1}$ It emphasises the coordinating and controlling role of the major studios in the international system of film production and consumption. It emphasises Hollywood's place in the system as a design centre, and it highlights the factors encouraging the international dispersal of production, including fluctuating currency exchange rates, differences in labour costs, and incentives offered by governments. Our argument here is that while the concept is useful, the term 'Global Hollywood' can obscure the initiative and involvement of individuals and organisations outside Hollywood in facilitating film production. Our interest is not in the actions and motivations of the Hollywood majors, but rather of those organisations, companies and people who intersect with Hollywood and work to bring production to particular places around the world. We argue that 'Global Hollywood' can best be understood as simultaneously global and local. We test some assumptions about the value and character of international production, and some of the underlying myths about 'runaway production' (the commonly used term to describe international production by Hollywood studios) and why production travels to particular places..$^{2}$ In the process, we will show how Hollywood in the contemporary era is only properly intelligible as a global phenomenon with particular local instantiations or iterations.

\section{Global Hollywood}

2 'Global Hollywood' does not only refer to those films made in southern California; rather it points to the fact that 'Hollywood' is a space of relations and flows, as much as it is a physical place. Global Hollywood not only means the production, distribution, and consumption of Hollywood films around the world, it also encompasses the money, people, companies and places from all over the world which are now involved in film production with Hollywood partners.

3 In the financing of films, the money for the majors' films and for international English language cinema-indeed much of all filmmaking-is drawn from around the world. For 
example, the Lord of the Rings trilogy was financed in part by German media funds, with substantial subsidy from the New Zealand government and taxpayers. ${ }^{3}$ Investment mechanisms known as 'hedge funds' often based outside the US in places like the Cayman Islands, provided $\$ 11$ billion in production finance for Hollywood films between 2004 and 2007. And in 2009, $\$ 325 \mathrm{~m}$ of the $\$ 825 \mathrm{~m}$ in production finance raised by Dreamworks came from the Indian company Reliance Big Entertainment. ${ }^{4}$ The internationalisation of film financing is of course by no means new. In the early 1970s, Italian film producer Dino De Laurentiis working with Dutch banker Frans Afman pioneered the system of using international pre-sales to finance De Laurentiis's production in the United States. ${ }^{5}$

4 The financing of Hollywood productions today does not only come from film distributors or "rich Europeans seeking tax advantages." It also comes from governments around the world which are increasingly providing a key part of the budget of films through various incentives and tax credit schemes to encourage production in their state or nation. Such incentives are now a global phenomenon; they are seen by industry players such as Andrew Smith, Group Corporate Affairs Director at Pinewood studios in the UK to be "essential for any territory to compete these days." And a web of incentives now covers most states of the US, much of Europe and increasingly some Asian countries, and has spawned consultants to help producers navigate through what has become a complex subsidy landscape. Places, investors, companies and governments inside and outside the US, are increasingly involved in the development of film and TV production. Drawing finance from a variety of international sources is a norm for international English language cinema in the midbudget range, like Australian director Peter Weir's 2010 film The Way Back. The $\$ 30 \mathrm{~m}$ budget of this film came from a fund controlled by National Geographic, and from the Abu Dhabi based production group Imagenation.

5 In terms of personnel, Hollywood has always attracted talent from around the world, both onscreen and off. Screen actors, directors, producers, writers, cinematographers, costume, set and sound designers, composers and editors from around the world are now involved in international production. And these are not only Hollywood productions as international collaboration is becoming a regular part of British, French, Korean and Chinese film production, to name just a few. It is most obvious in Hollywood cinema. Take the example of the Chronicles of Narnia: The Voyage of the Dawn Treader (Walden Media/20 $0^{\text {th }}$ Century Fox, 2010). This film has a British director, Michael Apted, a producer from New Zealand, Andrew Adamson, an Italian cinematographer, Dante Spinotti, and many Australians in various roles.

6 Global Hollywood is also evident in the terms of film settings and the locations of production. Weir's film The Way Back (Exclusive Films/National Geographic Films, 2010) is about seven men who escape from a Siberian gulag and travel overland through the Himalayas to India during the Second World War. The film was shot in India, Morocco and at the former Bulgarian national film studio now known as Nu Boyana, with postproduction undertaken in Australia.

7 Post production is another area of filmmaking that is now routinely an international process. One of the Australian digital effects companies that is working on The Way Back is Rising Sun pictures, based in Adelaide. This company, along with others based in the United Kingdom, and the United States, has worked on several of the Harry Potter films, among many others. 
8 The first of the Chronicles of Narnia films, The Lion, the Witch and the Wardrobe (Walden Media/Walt Disney Pictures, 2005), was shot in New Zealand, Poland, the UK and the USA. The second film in the series, Prince Caspian (Walden Media/Walt Disney Pictures, 2008), was shot in New Zealand, Poland, the UK, and at Barrandov Studios in Prague. The third film, Voyage of the Dawn Treader was shot over 8 months on the Gold Coast, in Australia, including some work at the Warner Roadshow Studios. These Gold Coast studios are in competition with Barrandov, with Nu Boyana, as well as with Fox Studios in Sydney, Central City Studios in Melbourne and many other facilities around the world. These places are involved in what Peter Dicken has called 'locational tournaments,' a global competition to host Hollywood and other production. ${ }^{8}$

\section{Design and Location Interests}

9 Our interest in the development of a Local Hollywood requires attention not only to the 'design interest' of Global Hollywood, but also to the 'location interests' that help to prepare and maintain a place for production that is often conceived and designed elsewhere. ${ }^{9}$ Those working in the location interest are not only concerned about ensuring the production of particular projects, but also are determined to ensure regular flows of production to a particular place. ${ }^{10}$

10 Decisions about story ideas, casting, crew and location-those things that affect the design of the project-will be determined by a combination of creative and economic concerns. All those involved in the creative development and planning of a film or television program share the 'design interest.' Their concern is to make the film or program to its full potential as cost-effectively as possible.

11 This is the view of production that informs much scholarly work on the phenomenon of so-called 'runaway productions,' a term that is commonly used to describe films and television programs made outside California by companies based in Los Angeles. ${ }^{11}$ The emphasis tends to be on what influences or affects the design interest. We felt that this view, while useful, does not properly account for the motivations of people and organisations in particular places whose principal purpose is to facilitate production in that place often (but not always) by pitching for projects that could be made in a number of locations. These people and organisations-which we term "agents of the location interest"-will often coordinate the assets and resources of a place for filmmakers.

\section{Local Hollywood on the Gold Coast}

We have been particularly interested in the Gold Coast because it is a place which, before a state-of-the-art film studio was built there in the late 1980s, had only a very limited history of production, and no existing crew base (Goldsmith, Ward and O'Regan 2010). It was what we call a 'greenfields location,' meaning a place with no or little prior experience of production. The Gold Coast was one of the first of the new wave of 'satellite production centres,' or Local Hollywoods. And in common with places like Murcia in Spain, Rosarito in Mexico (where Titanic (20 $0^{\text {th }}$ Century Fox/Paramount, 1997) was made), and Cape Town in South Africa, the Gold Coast has had an irregular history of production, subject to cycles of boom and bust. The Gold Coast is Australia's sixth 
largest city, and one of the country's major tourist destinations. It is located about a thousand kilometres North of Sydney, in Queensland, on the East Coast of Australia.

13 Since the Warner Roadshow Studios were built there in the late 1980s, over a hundred productions have been made on the Gold Coast. ${ }^{12}$ Many have not been widely seen in Australia, and apart from a number of high profile productions, most are largely invisible in critical and scholarly work. Where there is critical attention to them, or public discussion of the Gold Coast industry, it has often been negative, derogatory or derisory. Much of this criticism seems to take as a given the inherently inferior status of the international projects made on the Gold Coast compared with the valid and laudable Australian productions made elsewhere, usually in Sydney (New South Wales) and Melbourne (Victoria).

14 The diverse range of productions made on the Gold Coast since 1988 includes blockbuster-scale feature films like Chronicles of Narnia: The Voyage of the Dawn Treader (Walden Media/20 $/ 0^{\text {th }}$ Century Fox 2010), Nim's Island (Walden Media 2008) Peter Pan (Universal Pictures/Columbia Pictures 2003) and Scooby Doo (Warner Bros. Pictures 2002). In addition, the Gold Coast has hosted prime-time television series for American network television like Mission: Impossible (Paramount Television 1988-89), American cable television series like Lost World (Coote Hayes Productions 1998-2001) and Beastmaster (Coote Hayes Productions 1998 and 2001), and Australian television series like Sea Patrol (McElroy All Media 2006-2010) and The Strip (Knapman Wyld Television 2008). Two long-running daytime soap operas were made there in the mid 1990s-Pacific Drive (New World Television/Village Roadshow Pictures, 390 half-hour episodes between 1995 and 1997) and Paradise Beach (New World Television/Village Roadshow Pictures, 260 half-hour episodes between 1993 and 1994). And over 50 films and miniseries for television have been produced on the Gold Coast, most by incoming, international production companies.

15 In addition to this variety of drama production, the Gold Coast has since 2001 been a centre of reality-programming television production, with nine series of the Australian version of Big Brother (Southern Star Endemol 2001-2009) produced at the Dreamworld theme park including a weekly eviction special with a large, live audience. The Gold Coast hinterland and the luxury beachside hotel the Palazzo Versace have played host to ten series to date of the British version of I'm a Celebrity... Get Me Out of Here (Granada/ London Weekend Television 2002-2011), and five series of the German version of the format, Ich Bin Ein Star-Holt Mich Hier Raus (Granada 2004-2011).

16 The history of international production on the Gold Coast is instructive for analysis of the emergence over the last two or three decades of a global system of production with Hollywood at its centre. Over the last twenty years, the film industry based on the Gold Coast has not only helped to transform Hollywood, it has also expanded the range and types of films and television programs that have been produced in Australia. The studio was the brain child of an ambitious independent producer-distributor and a local government (the Queensland state government) that was keen to diversify the economy of the Gold Coast and to establish the region as a leisure, entertainment and tourism centre. Ultimately it would be an Australian company with global ambitions that would build the studio and the industry to the position it occupies today, although the real roots of this development lie in the events and trends that transformed Hollywood in the 1980s. 
17 From the 1980s it became routine for the majors, following the early lead of independent producers and aspiring mini-majors, to produce regularly overseas and to partner with companies located outside the United States..$^{13}$ Hollywood has always travelled, of course, but in the 1980s as the major studios were swallowed up by media corporations with global ambitions, money, talent, locations and markets outside the United States became fundamental to Hollywood's business. The larger independent distributors and production companies played their part too; they drew finance and experience from outside Hollywood and, without the burden of the majors' fixed costs in Los Angeles, were more adventurous in seeking new locations whether for cost or story reasons. ${ }^{14}$

18 One of the most important of these was the De Laurentiis Entertainment Group (DEG), run by Italian-American producer Dino De Laurentiis. Over the course of his career De Laurentiis had on numerous occasions taken enormous gambles based on little more than the strength of his faith in his instincts as a filmmaker and entrepreneur. As well as producing a number of Fellini's films in the 1950s and 1960s, he had acted as a fixer or intermediary between Hollywood producers and the Italian industry. He set up a studio, modestly named Dinocitta in Rome in the early 1960s, before moving to the US and becoming an American citizen in the early 1970s.

19 De Laurentiis hoped to build up DEG to compete directly with the majors, but a string of high-profile failures plunged the company into trouble by the mid-1980s. He began to seek new opportunities outside the United States. De Laurentiis had built a long and successful career producing films with international stars and crews both in major industry centres and in places with limited infrastructure and experience like Wilmington in North Carolina. In the early 1980s, De Laurentiis built a film studio there and in the process helped the city become one of the largest production centres in the United States.

20 In the mid-1980s, the profile of Australian films and filmmakers in Hollywood was higher than it had ever been following several Academy Award nominations and the critical and commercial success of a number of films made by Australian directors or starring Australian actors. When De Laurentiis visited Australia to assess potential locations for a film studio in August 1986, global buzz about local phenomenon Crocodile Dundee (Rimfire Films 1986) was deafening, even before the film was released in the US. Australian director Bruce Beresford, who made Crimes of the Heart (DEG 1986) for De Laurentiis in 1986, and Terry Jackman, broker of the distribution deals for Crocodile Dundee and former head of Australian cinema chain Hoyts, convinced De Laurentiis that Australians were capable of making the films he needed to trade his way out of trouble. De Laurentiis was also excited by the size of the Australian theatrical and video markets, and by the potential to draw on new sources of capital and new partners in the production of content for international distribution through his network of companies and associates. A deal was soon brokered with the Queensland state government, which had been considering building a film studio since the late 1970s.

21 The move into Australia fitted De Laurentiis's history of international engagement and innovation, and was consistent with his approach to film business. As Dinocitta and Wilmington demonstrated, he had built successful production facilities from scratch before. A new company, De Laurentiis Limited (DEL) was set up in Australia, and the stage was set for Beresford to make Total Recall with Patrick Swayze on the Gold Coast. But De Laurentiis's American company DEG's 1986 slate of releases in the US all failed, 
the company's share price plummeted, and senior executives departed amid an investigation by the US Securities and Investments Commission. De Laurentiis himself would ultimately be forced to stand down as President. These financial troubles forced his withdrawal from Australia just before the official opening of the studio in 1987.

22 Fortunately for the studio, an Australian media company took over the development. Village Roadshow had begun life as an operator of drive-in cinemas in the 1950s, growing to become Australia's largest production, distribution and exhibition company..$^{15}$ The company's management saw the studio as a key part of an ambitious plan for global expansion.

23 After considerable lobbying in Hollywood, Village Roadshow managed to persuade Warner Bros to become a partner. Through the use of the Warner's name, the studio gained instant attention, reputation by association, and entry to the majors' network of contacts and projects. Another major studio, Paramount, became the Gold Coast's first client in 1988, with the revival of the television series Mission: Impossible and a new series Dolphin Cove. Mission: Impossible moved to Melbourne for a second series, while Dolphin Cove only lasted a single season.

24 Over the years Village Roadshow has adopted a variety of strategies to pull production to the Gold Coast. Mission: Impossible represented the first strategy to develop the Gold Coast as a location for international production. Village Roadshow targeted opportunistic international producers looking for cheap production services, favourable exchange rates, and local financial incentives to minimise production costs. Later strategies involved making its own feature films for international distribution, producing series for Australian television while retaining an eye to international markets, and co-producing international series. The studio's slate of productions and prosperity were closely tied to Village Roadshow's corporate ambitions as it transformed from a private family company focused on Australian production, distribution and exhibition, to a publicly listed company with diverse media holdings in Australia and around the world. Warner Bros, the other partner in the studio, was honoured first in the studio's title (Warner Roadshow Movieworld Studios), but was always far more interested in the prospects and fortunes of the Movieworld theme park which was built next door to the studios and opened in 1991.

25 This focus on the theme park was still highly significant for the future of the Gold Coast film industry, as it demonstrated the synergies that could be developed between film and television production, and other leisure industries and infrastructure.

The Gold Coast is a place in a constant state of transformation. One of the keys to its success as a film and television production location is that from an early stage the Gold Coast seemed to understand the importance of private investment and transnational corporations in mediating the development, governance and future of the city. This made it an especially welcoming place for De Laurentiis and later Village Roadshow and Warner Bros. The city has been defined by large-scale, entrepreneurial developments often as part of public-private partnerships reliant on sympathetic planning regulations and soft loans from public coffers. Successive local and state governments have fostered the image and practice of the Gold coast as a 'yes' place prepared to do almost anything to accommodate particular industries and developments. The origins of this 'can do' culture lie in the ways this "frontier city" understands itself and projects itself to the world (Breen 2004). ${ }^{16}$ 
27 Throughout its history, the Gold Coast's abiding curse and advantage has been a readiness to change in order to accommodate the desires and fantasies of waves of visitors and new residents. The city has been developed, remodelled and (re)named to invoke and juxtapose other places-there are parts of the Gold Coast called Southport, Miami Beach, Sorrento, the Isle of Capri-or to evoke images of idyllic luxury and exotic exclusivity-Surfers Paradise, Sanctuary Cove. The city survives and thrives on its capacity to produce new ideas and new experiences for tourists and prospective investors. It is relentlessly present- and future-focused, attuned to the fulfillment and anticipation of desire.

28 The city's willingness, or rather need, to be in a state of constant transformation and change is a critical condition for any place with ambitions to host Hollywood production. Over the last two decades, many places around the world have sought to profit from Hollywood's new mobility, but few have convincingly replicated the Gold Coast's blend of attitude and ambition because few have been so committed to the kinds of constant change that international film production consistently requires.

29 The Warner Roadshow studio complex literally opened up new territory for Australian filmmakers and for filmmaking in Australia. It was the cornerstone of the infrastructure necessary to create an industry on the Gold Coast. It was built to service and facilitate international production, and to establish a commercial cinema in a country where since the revival in the early 1970s filmmaking had relied on support from the public purse. On the Gold Coast, as in Vancouver, Canada, where a similar satellite industry had been established in the mid-1980s, Hollywood was not considered an obstacle to the development of a film industry, but rather a means to build local production capacity through the development of a range of services to film production. While the industrial and financial situation forced strategies for the studio to change, and while the facility would struggle for a number of years, a critical mass of crew and ancillary services began to grow and the Gold Coast gradually established itself as an important site of Australian and international film and television production. In the process it transformed film and television production in Australia, and contributed to the creation of "global Hollywood."

30 The Global Hollywood thesis has been useful in understanding the internationalisation of Hollywood over the last couple of decades. But we found in our research on the Gold Coast that the Global Hollywood approach did not entirely account for the variety of motivations and interests at work in the Gold Coast development. Indeed, the Gold Coast has become since 1988 an important satellite centre for Hollywood originated or designed films and television programs, but to look at the evolution of the industry on the Gold Coast solely from the perspective of migrating productions or of Hollywood is to miss much of what has happened on the Gold Coast. Instead, if we look at the particular local circumstances which led to the studio development we find a different picture that is also instructive for thinking about other places in the world that like the Gold Coast seek to compete to host and service some of the high profile and highly mobile international film and television production.

31 It is increasingly the case, as it was on the Gold Coast, that agents of the location interest including government ministers and departments as well as local business interests will work to establish production infrastructure such as film studios in order to draw production to that place. Often this will be done in conjunction with a major film industry figure or firm. In the Gold Coast's case, that was Dino De Laurentiis, and 
later the Hollywood major studio Warner Bros. Their role was undeniably important, but just as critical was the role and ambitions of local players: the Queensland government and Village Roadshow.

32 The Gold Coast was the first place in the southern hemisphere to host production by Hollywood majors on a regular basis, something that is now actively sought by other major Australian centres just as it is the subject of competition between locations around the world. The pursuit of the Gold Coast location interest over the last twenty years has much to teach other centres in both its successes and failures. The partnership between Village Roadshow and Warner Bros that enabled the studios and as a result the industry itself to survive the drama of Dino De Laurentiis's departure is instructive for ambitious production companies that seek to internationalise or diversify their business. The ways in which the Gold Coast contributed to the development of the split location production system that is now the norm around the world provide valuable precedents for aspiring and established centres. The experience of building and growing this "greenfields location" and especially the synergies that have developed with other industries and services, particularly tourism and theme parks, are enormously useful to the many places now seeking to participate in the lucrative market for international production. In short, the Gold Coast story has much to teach industry practitioners, policymakers and scholars about the workings of contemporary film and television production, about the need for and consequences of particular types of policy settings and attitudes to production, about the approaches we must take to the study of locating international film and television production, and about the local aspects of Global Hollywood.

\section{BIBLIOGRAPHY}

Breen, Sally. "Future Frontier." PhD thesis, Griffith University, 2004.

Dicken, Peter. Global Shift: Mapping the Changing Contours of the World Economy. Thousand Oaks, CA: Sage, 2007.

Goldsmith, Ben. “'The Comfort Lies in All the Things You Can Do': The Australian Drive-in, Cinema of Distraction." Journal of Popular Culture, 331 (1999): 153-64.

Goldsmith, Ben. "If You Build It ... Film Studios and the Transformative Effects of Migrating Media Production.” In Locating Migrating Media, eds. Greg Elmer et al. (Lanham, MD: Lexington Books, 2010) 103-27.

Goldsmith, Ben, Susan Ward and Tom O'Regan. Local Hollywood: Global Film Production and the Gold Coast. St Lucia, Qld: University of Queensland Press, 2010.

Grant, Peter S., Wood. Chris Blockbusters and Trade Wars: Popular Culture in a Globalized World. Vancouver: Douglas \& McIntyre, 2004.

Kezich, Tullio, Levantesi, Alessandra. Dino: The Life and Films of Dino De Laurentiis. New York: Miramax Books, 2004. 
Miller, Toby, et al. Global Hollywood. London: British Film Institute, 2001.

O'Regan, Tom, Ward, Susan. "Experimenting With the Local and the Transnational: Television Drama Production on the Gold Coast." Continuum, 201 (2006): 17-31.

O’Regan, Tom, Ward, Susan. "Managing Uncertainty: Defining the Location Interests of a Greenfields Location." In Cross-Border Cultural Production: Economic Runaway or Globalization? eds. Janet Wasko and Mary Erickson. Ithaca, NY: Cambria Press, 2008. 155-86.

Prince, Stephen. A New Pot of Gold: Hollywood Under the Electronic Rainbow 1980-89, History of the American Cinema vol. 10. Berkeley: University of California Press, 2002.

Roxborough, Scott. "The Price is Right." Hollywood Reporter, September 25-27, 2009, 21-27.

Szalai, Georg, Bond, Paul. “Queasy Money.” Hollywood Reporter, August 28-30, 2009, 26-27.

Tzioumakis, Yannis. American Independent Cinema: An Introduction. Edinburgh: Edinburgh University Press, 2006.

United States International Trade Administration (USITA). The Migration of US Film and Television Production: Impact of 'Runaways' on Workers and Small Business in the US Film Industry. Washington, D. C.: US Department of Commerce, 2001.

Ward, Susan, O’Regan, Tom. "The Gold Coast Movie-of-the-Week: A North American Form in its Australian Context." Metro, 143, (2004) 100-9.

Wasser, Frederick. "Is Hollywood America? The Trans-Nationalization of the American Film Industry." Critical Studies in Mass Communication, 12 (1995), 423-37.

Wyatt, Justin. High Concept: Movies and Marketing in Hollywood. Austin: University of Texas Press, 1994.

\section{NOTES}

1. Toby Miller et al., Global Hollywood (London: BFI, 2001).

2. United States International Trade Administration, The Migration of US Film and Television Production: Impact of "Runaways" on Workers and Small Business in the US Film Industry (Washington, D.C.: US Department of Commerce, 2001).

3. Peter S. Grant and Chris Wood, Blockbusters and Trade Wars: Popular Culture in a Globalized World (Vancouver: Douglas \& McIntyre, 2004) 292.

4. Georg Szalai and Paul Bond, "Queasy Money," Hollywood Reporter, August 28-30, 2009, 26.

5. Frederick Wasser, "Is Hollywood America? The Trans-nationalization of the American Film Industry," Critical Studies in Mass Communication, 12, (1995): 423-37.

6. Georg Szalai and Paul Bond, "Queasy Money," Hollywood Reporter, August 28-30, 2009, 26.

7. Scott Roxborough, "The Price is Right," Hollywood Reporter, September 25-27, 2009, 22.

8. Peter Dicken, Global Shift: Mapping the Changing Contours of the World Economy (Thousand Oaks, CA: Sage, 2007) 238.

9. Ben Goldsmith and Tom O'Regan, The Film Studio (Lanham, MD: Rowman \& Littlefield, 2005) 2-7, 41-62.

10. Ben Goldsmith, "If You Build It ... Film Studios and the Transformative Effects of Migrating Media Production," in Locating Migrating Media, eds. Greg Elmer et al. (Lanham, MD: Lexington Books, 2010) 103-27. 
11. United States International Trade Administration, The Migration of US Film and Television Production: Impact of "Runaways" on Workers and Small Business in the US Film Industry (Washington, D. C.: US Department of Commerce, 2001).

12. Tom O'Regan and Susan Ward, “Managing Uncertainty: Defining the Location Interests of a Greenfields Location," in Cross-Border Cultural Production: Economic Runaway or Globalization?, eds. Janet Wasko and Mary Erickson (Ithaca, NY: Cambria Press, 2008) 155-86; Susan Ward and Tom O’Regan, 'The Gold Coast Movie-of-the-Week: A North American Form in its Australian Context,' Metro, 143, (2004): 100-9.

13. Stephen Prince, A New Pot of Gold: Hollywood Under the Electronic Rainbow 1980-89, History of the American Cinema vol. 10 (Berkeley: University of California Press, 2002).

14. Justin Wyatt, High Concept: Movies and Marketing in Hollywood (Austin: University of Texas Press, 1994); Yannis Tzioumakis, American Independent Cinema: An Introduction (Edinburgh: Edinburgh University Press, 2006).

15. Ben Goldsmith, “'The Comfort Lies in All the Things You Can Do': The Australian Drive-in, Cinema of Distraction," Journal of Popular Culture, 331 (1999): 153-64.

16. Sally Breen, “Future Frontier," PhD thesis, Griffith University, 2004.

\section{ABSTRACTS}

The term 'Global Hollywood' describes the international reach of the major Hollywood studios, and the internationalisation of financing, production, distribution and exhibition of films made by the majors, or by their subsidiaries and partners. In this article we describe how one place, the Gold Coast in the Australian state of Queensland, became a 'Local Hollywood' or a regular location for such international film and television production.

\section{INDEX}

Keywords: Global Hollywood, Local Hollywood, film production, design interests, location interests

\section{AUTHORS}

\section{BEN GOLDSMITH}

Ben Goldsmith is a research fellow in the Centre for Critical and Cultural Studies at the University of Queensland, Australia. Susan Ward is a researcher with the School of English, Media Studies and Art History at the University of Queensland, Australia. Tom O'Regan is a Professor of Cultural and Media Studies at the University of Queensland, Australia. He is the author of Australian Television Culture (1993) and Australian National Cinema (1996). Ben Goldsmith and Tom O'Regan published The Film Studio: Film Production in the Global Economy in 2005. With Susan Ward, they are also the co-authors of Local Hollywood: Global Film Production and the Gold Coast (2010). University of Queensland 


\section{SUSAN WARD}

Susan Ward is a researcher with the School of English, Media Studies and Art History at the University of Queensland, Australia. With Ben Goldsmith and Tom O'Regan, she is the co-author of Local Hollywood: Global Film Production and the Gold Coast (2010).

University of Queensland

\section{TOM O'REGAN}

Tom O'Regan is a Professor of Cultural and Media Studies at the University of Queensland, Australia. He is the author of Australian Television Culture (1993) and Australian National Cinema (1996). Tom O'Regan and Ben Goldsmith published The Film Studio: Film Production in the Global Economy in 2005. With Susan Ward, they are also the co-authors of Local Hollywood: Global Film Production and the Gold Coast (2010).

University of Queensland 